This is the author's Post-print version (final draft post-refereeing as accepted for publication by the journal). The definitive, peer-reviewed and edited version of this article is published as: van Ham M. and Büchel F. (2006) Unwilling or Unable? Spatial and Socio-Economic Restrictions on Females' Labor Market Access. Regional Studies 40(3), 1-12. http://dx.doi.org/10.1080/00343400600632663

\title{
Unwilling or Unable? Spatial and Socio-Economic Restrictions on Females' Labor Market Access
}

\author{
Maarten van Ham* and Felix Büchel († July 12, 2004)** \\ *Utrecht University, Faculty of Geosciences, Urban and Regional research centre Utrecht \\ (URU), P.O. Box 80.115, 3508 TC, The Netherlands, Phone +31 (0)30 253 1370/1399, Fax \\ +31 (0)30 253 2037, E-mail: m.vanham@geo.uu.nl \\ *** Max Planck Institute for Human Development, Lentzeallee 94, 14195 Berlin, Germany \& \\ Faculty of Economics, Technical University of Berlin, Berlin, Germany \& Department of \\ Political and Social Sciences, Free University of Berlin, Berlin, Germany \& Department of \\ Longitudinal Data and Microanalysis, German Institute for Economic Research DIW, Berlin, \\ Germany \& IZA Bonn, Germany
}

\begin{abstract}
We analyse the effects of regional structures on both females' willingness to work and the probability of being employed for those willing to work. Special permission was granted to link regional data to individual respondents in the German Socio-Economic Panel (GSOEP). Results of a bivariate probit model correcting for sample selection show that high regional unemployment discourages women from entering the labor market. Those who are willing to work find it easier to do so if living in regions with low regional female unemployment rates, at a short distance from the next agglomeration, and - for mothers with a high density of childcare provision.
\end{abstract}

Keywords: Female labor supply; regional labor markets; childcare provision; bivariate probit model; Germany

JEL: R23; J13; J21; J64

\section{INTRODUCTION}

The labor-force participation of women has increased dramatically in most European and other industrialized countries over the last few decades. In some countries the labor-force participation rates for mothers with infants have nearly doubled in that time (RUBERY et al., 1998; 1999). These changes in participation are related to fundamental changes in gender roles, participation in education, family organization, and the labor market (ODLAND and ELLIS, 1998). The increase of female labor-force participation has led to a profound interest in the causes of the differences in women's participation rates both within and between countries (for an overview, see VAN DER LIPPE and VAN DIJK, 2002).

Although participation rates have increased, women still have considerably lower participation rates than men; women work in different sectors and - on average - for lower wages (RESKIN, 1993; MENCKEN and WINFIELD, 2000). These facts suggest that, compared with men, women face serious barriers to labor-force participation. Microeconomic approaches seeking to explain lower female participation based on the theory of 
labor supply assume that women strive for utility maximization and concentrate on time and income constraints (VAN DIJK and SIEGERS, 1996). Most micro-economic approaches to women's labor supply have placed heavy emphasis on personal and household characteristics as the determinants of labor supply. Much less attention has been paid to macro-level labor market conditions external to the individual (ODLAND and ELLIS, 1998), although there is increasing interest in explaining women's employment by a combination of both individual characteristics and features of the macro-context (VAN DER LIPPE and VAN DIJK, 2002).

There is a long tradition in geography of seeking to understand female employment in terms of the constraints of daily commuting and local labor market conditions. The basic argument that a lack of access to employment opportunities leads to non-employment originates from Kain's spatial mismatch hypothesis (KAIN, 1968). The framework was "originally coined to describe a broad set of geographical barriers to employment for AfricanAmerican inner city residents (PRESTON and MCLAFFERTY, 1999: 388)," but the issue widened over the last decade to encompass gender differences in participation as well. The idea is that most women face severe day-to-day space and time constraints because of their domestic workload, which limits the time available for work and getting to work (HANSON and PRATT, 1990; PRATT and HANSON, 1991). These constraints often form a serious geographical barrier to labor-force participation because they spatially restrict the opportunity set of available jobs (VAN HAM, 2002). Poor geographical access to suitable jobs is thought to influence employment opportunities and labor market outcomes negatively at the individual level (KAIN, 1968; PRESTON and MCLAFFERTY, 1999 on the spatial mismatch hypothesis). Other authors have suggested that geographical access to childcare facilities is an important factor determining access to employment opportunities for mothers with young children (KWAN, 1999; VAN DIJK and SIEGERS, 1996; VAN HAM and MULDER, 2003).

Most of the literature on spatial barriers to female labor-force participation focuses on the direct effect of access to jobs on the probability of having a paid job (see for example WARD and DALE, 1992). The mechanism studied is straightforward: it is hypothesised that the greater the number of suitable jobs that can be reached within acceptable commuting time, the easier it is to find a suitable job. Besides this direct effect of access to jobs on female labor-force participation, there might also be a second, indirect, mechanism at work. Some women might become discouraged in their job search and fail to enter the labor force because they consider the probability of finding a suitable job to be very low given the lack of suitable local job opportunities (SEE FISHER and NIJKAMP, 1987; VAN HAM et al., 2001 on the discouraged worker hypothesis). In other words, it can be hypothesised that some women in the potential labor force state that they do not want a paid job, but would in fact state otherwise if they had access to suitable employment. The question is thus to what extent these women are unable to find a suitable job, or are unwilling to do so. An answer to this key question would provide insight into the mechanisms underlying female labor-force participation and the size of the hidden labor force. To date, the difference between the two mechanisms in operation has received little attention in the literature.

The principal argument of this paper is that, in order to fully understand the effect of the spatial context on female labor-force participation, two phases of participation should be distinguished. The paper addresses the question of the extent to which the opportunity structure of the regional labor market has a double-edged effect on female labor-force participation. It was hypothesised that the opportunity structure influences both the decision to enter the labor market (willingness to take up a paid job) and the probability for those willing to work of being in employment. The outcome of both effects might be the same - nonemployment - but the mechanisms leading to this outcome are different. The hypotheses are tested for women living in the Western part of Germany. Aspects of the German regional labor market considered are the female unemployment rate, geographical accessibility to employment opportunities, and the regional availability of childcare. The hypothesis was 
tested using individual level data from the 2001 wave of the German Socio-Economic Panel (GSOEP). This representative dataset, which is readily accessible to the scientific community, includes detailed information on the individual and household characteristics of more than 22,000 respondents. For this article, two unique features of the GSOEP data were used. First we utilized a set of variables identifying the hidden labor market reserve. Second, we were given special permission to link regional labor market characteristics with individual respondents. The effect of the regional opportunity structure on female employment was estimated using a bivariate probit model that corrects for sample selection.

\section{(SPATIAL) DETERMINANTS OF FEMALE LABOR-FORCE PARTICIPATION}

A large body of literature reports studies of female labor-force participation taking a microeconomic approach and placing a heavy emphasis on personal and household characteristics as determinants of female labor supply. Human capital theory is often the starting point for these studies (BECKER, 1962). Within this framework, it is assumed that women strive for utility maximization: female labor-force participation is explained mainly in terms of time and income constraints. The idea is that whether or not women participate in the labor market is determined by a substitution mechanism of non-paid time and paid labor time (VAN DIJK and SIEGERS, 1996). The greater a woman's potential wage, the greater are the opportunity costs of non-paid time. This statement implies that women with a high potential wage will have a higher probability of being engaged in paid work (for empirical evidence, see ERMISCH, 1989; LEIBOWITZ et al., 1992). A person's level of education is a good proxy for earning capacity, so it can be expected that the higher the level of education, the higher is the probability of a woman participating in the labor market. A second income-related factor that is known to explain female labor supply is non-labor income. The greater a woman's non-labor income, the lower is the probability that she works (see VAN DIJK and SIEGERS, 1996). Non-labor income normally refers to the male partner's earnings, but can also refer to alternative income resources.

Age is also a factor known to influence labor supply. A negative effect of age can be expected from health problems. It may therefore be expected that female labor supply will drop with age (HENKENS et al., 1993). Cohort effects may also play a part in the effect of age on female labor supply. Many older women have grown up with the idea that they were supposed to become a full-time housewife and mother. Younger women have grown up with more modern ideas towards labor supply and will therefore more often be engaged in paid labor (VAN DIJK and SIEGERS, 1996).

A final major factor known to influence female labor supply is the presence of children in the household. Many women stay outside the active labor force and become fulltime housewives, especially when there are young children in the household. Making such a choice seems inconsistent with the assumption that all individuals maximize the utility of their accumulated human capital. The new home economics theory (BECKER, 1976, 1991) offers a theoretical framework that resolves this inconsistency. According to this theory, a mother's labor participation decision is purely financial and depends on her earning capacity. If a mother's earning capacity is low, she will decide to remain a full-time housewife. Mothers who have a high earning capacity may decide to participate on the labor market and contract out part of the domestic workload (see also VAN HAM et al., 2001). Because younger children need more care than older children, the negative effect children have on the labor supply of mothers can be expected to decrease with the age of the children.

There has been considerable criticism of the human-capital based approach as described above, because women's position on the labor market is seen as the outcome of rational decisions (see, for example, HANSON and PRATT, 1990; PRATT and HANSON, 
1991 on occupational segregation). According to the criticism leveled, more attention should be paid to constraints. For example, an assumption that women make a rational decision not to be engaged in paid labor because they have children is too simple. It is highly likely that many non-employed mothers would like to have a paid job, but encounter too many barriers on their path to employment.

The argument of this paper is that the mechanisms underlying female employment are too complicated simply to study employment versus non-employment and that the opportunity structure of the regional labor market is an important barrier to employment. In order to understand the mechanisms, two phases of participation should be distinguished. In the first phase, women decide whether or not to participate in the labor market. In principle, all women are part of the potential labor force; however, only those willing to be in paid employment are part of the active labor force and therefore 'at risk' of actually being employed. The second phase is the job search of those willing to work and therefore in the active labor force. A successful search leads to employment. We argue that the opportunity structure of the regional labor market influences both phases of participation and that it is necessary to consider both phases in order to fully understand the mechanisms at work. Looking at both phases provides more insight than looking at female labor-force participation in terms of employment versus non-employment.

A key question with regard to the first phase is what determines whether women are willing to work. Not all women want a paid job. MOSELEY and DARBY (1978) distinguish between 'opportunity factors' and 'desire factors'. Desire factors arise from the social, cultural, and familial environment within which women live (MOSELEY and DARBY, 1978, 297). Especially when (young) children are present, some women prefer the role of full-time housewife and mother. However, the numerous restrictions women face that make it difficult to take up paid employment, especially when they have children, are also widely recognized (see, for example, HANSON and PRATT, 1995). It is very likely that some women who would like to work if the opportunity arose state that they do not want to do so because they perceive the probability of actually getting a job to be very low.

In the labor market literature, this effect is known as the discouraged worker effect (FISHER and NIJKAMP, 1987; VAN HAM et al., 2001). According to the discouraged worker hypothesis, people with poor labor market expectations become discouraged in their job search and leave or fail to enter the labor force, because the probability of finding a suitable job after a certain period of time is too low. Poor labor market prospects, leading to discouragement, may result from individual characteristics, either real or ascribed. Discouragement can also be caused by opportunity factors - the structure of the labor market (VAN HAM et al., 2001). Poor access to employment opportunities may lead people to become discouraged in their search for jobs. If, given the expected returns, the costs of a job search are too high, people may give up searching.

\section{Labor-force participation and the opportunity structure of the regional labor market}

The opportunity structure of the regional labor market is expected to have an effect on both the decision to enter the labor force and the probability of those willing to work being in employment. The spatial link between the opportunity structure of the local labor market and the individual is expressed by the commuting tolerance of workers. Commuting tolerance is the maximum time a worker is able or willing to spend on commuting. A low commuting tolerance restricts the choice set of employment opportunities open to a person. This line of reasoning is central in the spatial mismatch literature (KAIN, 1968; PRESTON and MCLAFFERTY, 1999; VAN HAM, 2002). If there is a spatial mismatch between workers and jobs, and workers are not able to travel to the jobs, this mismatch leads to unemployment.

There has been considerable research on how labor markets are localized by the limited time (and therefore distance) that workers can commute on a daily basis. Owing to a 
limited commuting tolerance, the employment opportunities available to most women (and men) are confined to locations within daily commuting of their homes (see ODLAND AND ELLIS, 1998). Research shows that women are particularly sensitive to commuting times, and that men will tolerate longer commuting times than women (MADDEN, 1981; GORDON et al., 1989; JOHNSTON-ANUMONWO, 1992). Women with children have been shown to be particularly averse to long commuting times (ROUWENDAL, 1999). Compared with men, women are more likely to have to cope with severe day-to-day space and time constraints dictated by their domestic workload (HANSON AND PRATT, 1991). If there are no jobs available within reasonable commuting time, unemployment will ensue. In this paper we argue that this mismatch can also lead to discouragement and, therefore, non-employment.

A spatial mismatch between workers and jobs may be expressed by a high regional unemployment rate, which indicates a mismatch between demand and supply on the regional labor market (SIMPSON, 1992). Because men and women operate to some extent on different segments of the labor market, male and female unemployment rates may differ within regions (HANSON and PRATT, 1995). We would therefore expect women living in regions with a high female unemployment rate to be less likely to express a willingness to work (be part of the active labor force) than women in regions with a low female unemployment rate. Another indicator of poor access to employment opportunities is the time a worker takes to travel to the nearest concentration of job opportunities (see BÜCHEL and VAN HAM, 2003). The longer the time, the more difficult finding a suitable job would be. We would expect women living in locations further from concentrations of employment opportunities to be less likely to express a willingness to work.

For women with young children, poor access to childcare may also lead to discouragement. Most research on the effects of the provision of childcare on mothers' laborforce participation concentrates on the affordability of childcare (see, for example, BERGER and BLACK 1992; BLAU and HAGY 1998; BLAU and ROBBINS 1988, 1991; CONNELLY 1991, 1992). Following HECKMAN (1974), most studies focus on the costs of childcare relative to female wages. The underlying idea is that, if a large share of the income generated by paid employment has to be spent on childcare, working outside the home is simply not worthwhile. However, if mothers are to be able to use childcare, it should not only be affordable, but also available. Several authors have asserted that geographical access to childcare facilities is an important factor determining access to certain job locations for women with young children (MICHELSON 1985, 1988; TIVERS 1985, 1988; HANSON and PRATT 1988, 1990; ENGLAND 1996A, 1996B; GILBERT 1998; KWAN 1999). Consequently, for many mothers, good geographical access to childcare facilities is a precondition for access to job opportunities. When childcare is not available, discouragement may follow. We would therefore expect mothers with poor access to childcare facilities to be less likely to express a willingness to work than mothers with good access to childcare facilities.

For those women willing to have a paid job (and therefore join the active labor force), the probability of actually having a job is expected to be influenced by the opportunity structure of the local labor market (see also HANSON et al., 1997). A lack of job opportunities is a well-established explanation of unemployment in the spatial mismatch literature (for an overview, see PRESTON and MCLAFFERTY, 1999). Based on the above, we formulated three hypotheses concerning the influence of the regional opportunity structure on the probability of those women who are willing to work actually having a job. First, we expected a high regional unemployment rate to negatively influence the probability that those willing to work are actually in employment. A high regional unemployment rate indicates fierce competition on the regional labor market, and finding a suitable job under these conditions is more difficult. Second, we expected women who live far away from large concentrations of employment opportunities to run a high risk of unemployment. For these 
women, the costs of finding a suitable job are particularly high. Third, we expected the probability that mothers with poor access to childcare were in employment to be low because it is difficult for them to find a job that they can combine with caring for small children.

\section{WOMEN ON THE GERMAN LABOR MARKET}

Before we continue with the empirical section of the paper it is useful to review briefly women's position on the German labor market. In 2003, about 58 percent of all women in the Western part of Germany aged between 15 and 65 were employed. Single women are employed slightly more often than women with a partner. A little over 17 percent of the working women have a full-time job and 41 percent of them have a part-time job (STATISTISCHES BUNDESAMT, 2004). Working part-time is strongly gender-related, since only 3 percent of working men have a part-time job. The percentage of women working part-time has almost doubled in the last 20 years; research shows that most women work parttime by choice (HOLST and SCHUPP, 2001).

There is a clear gender segmentation by sector on the German labor market. In comparison with men, women are overrepresented in jobs in the business and commerce sector, banking and insurance, and other services; women are underrepresented in the production sector. There are large differences in sector between full-time and part-time working women. More than 45 percent of women working full-time work in the production sector, 21 percent in business and commerce, 13 percent in banking and insurance, and 13 percent in other services. Of the part-time working women, only 29 percent of them work in the production sector, 32 percent in trade and commerce, 10 percent in banking and insurance, and 19 percent in other services (STATISTISCHES BUNDESAMT, 2003). The gender segmentation and differences in sector between full-time and part-time jobs show clearly that men and women operate to some extent on different labor markets.

In the last few decades there have been substantial changes in West German mothers' labor force participation. Between 1972 and 2000 it rose from 40 percent to 63 percent for mothers (aged between 15 and 65) with children under the age of 18 (BÜCHEL and SPIESS, 2002; STATISTISCHES BUNDESAMT, 2001). In the year 2000 a further 7 percent of these mothers were actively looking for a job. There are large differences in the labor force status of mothers with respect to the number and age of their children (KLAMMER et al., 2000). The fewer the children in the household and the older the youngest child, the greater is the probability that the mother works. More than 70 percent of mothers whose youngest child is aged between 15 and 18 work, compared with only 48 percent of mothers with children under the age of 3. Women with children work part-time more often than do women without children. Research shows consistently that those German mothers who work part-time report being happier with their lives than do those mothers who work full-time (DIW, 2003).

The labor force participation of single mothers in the Western part of Germany is relatively high (KLAMMER et al., 2000). There are no large differences in labor force participation between single mothers and mothers with a partner. More than 46 percent of single mothers with children under the age of 3 are employed, compared with 48 percent of mothers living with a partner. More than 73 percent of single mothers with children aged between 15 and 18 are employed, compared with 70 percent of mothers living with a partner (STATISTISCHES BUNDESAMT, 2001). The increase in the labor force participation of mothers can be attributed entirely to the increase in part-time working. Since the 1970s the percentage of full-time working mothers has even decreased a little (ENGSTLER, 1998). Currently, 74 percent of all working mothers with children less than 18 years of age work part-time (STATISTISCHES BUNDESAMT, 2002). 
There are significant differences in income between men and women in the Western part of Germany, although these differences are tending to decrease. In 2003, full-time working women earned on average a gross income of $€ 2,408$ a month, compared with men's average gross income of $€ 3,081$; this is a 22 percent difference. Part-time working women earned on average $€ 1,256$ and part-time working men $€ 1,414$ a month (STATISTISCHES BUNDESAMT, 2003). Since 1995, on average, female incomes increased by 20 percent while male incomes increased by only 15 percent. The most important reasons for the gender differences are that, compared with men, women work in jobs with fewer responsibilities, in smaller firms, and in sectors with lower wages. Furthermore, women have on average a shorter tenure than men and lower qualifications. But, even after controlling for all these factors, women still earn less than men in the same type of job (STATISTISCHES BUNDESAMT, 2003).

In Germany, there is an extensive government income security program which provides a safety-net for low or non-income households. It is very likely that the existence of this safety-net influences female labor-force participation (see MCGINNITY, 2002 for an overview and comparison with Britain). In Germany, a federal law guarantees people a minimum income through social security benefits (Sozialhilfe). This income is granted without any condition of age as long as the person concerned does not find any other resource (accommodation and healthcare expenses are covered). The Socialhilfe is cut substantially should a person receiving social security benefits refuse a job considered to be acceptable. The social security benefits for a single person amount to about $€ 322$ a month; in 2004 about 3 percent of women and 2 percent of men aged over 18 received benefits. People who become unemployed involuntarily can count on unemployment benefits (Arbeitslosengeld and Arbeidslosenhilfe) and low income households can also count on housing benefits (Wohngeld).

There are also benefit programs especially designed for households with children. First, regardless of their income, parents can obtain child benefits (Kindergeld) for children up to the age of 18. Parents can also receive child benefits for children aged over 18 as long as they are in full-time education (up to the age of 27). Parents receive $€ 154$ a month for each of their first three children and $€ 179$ for each subsequent child. Second, for low income parents who work for a maximum of 30 hours a week, there are also child-rearing benefits (Erziehungsgeld) to subsidize the upbringing of their children. The maximum amount parents can obtain varies from $€ 300-€ 450$ a month for one or two years.

The above description of the position of women on the German labor market gives important insights into the context needed for understanding female labor-force participation in Germany. The figures presented show that more than half the German women aged between 15 and 65 have a paid job. The percentage of working women is higher when we look only at the women in, for example, the age range of 25-45; this difference can be partly explained by cohort effects. In the light of the research presented in this paper, the category of non-employed women is interesting, since this group is relatively large and research shows that most non-employed West German women, and especially mothers, wish to obtain a paid job in the near future (see BÜCHEL and SPIESS, 2002). This paper seeks to provide more insight into the barriers to employment, especially for women with children. We do so by focusing on spatial barriers on the regional level and by distinguishing two phases of participation. 


\section{DATA AND METHODOLOGY}

\section{Data}

The individual level data used in this paper were taken from the 2001 wave of the German Socio-Economic Panel (GSOEP) with information on 22,351 respondents. This database is administered by the German Institute for Economic Research (DIW) in Berlin (see WAGNER et al., 1993; SOEP GROUP, 2001, for details). The analyses were restricted to women aged between 18 and 60 who were living in former West Germany. We excluded students, trainees, and respondents who reported that they were unable to work owing to a disability. Following this selection procedure, the dataset comprised 5508 female respondents.

To test our hypotheses, we needed to analyse both willingness to work (being part of the active labor force) and employment status among those willing to work. The German Socio-Economic Panel includes some unique variables that make it possible to identify the hidden labor force reserve, that is to say those who are in principle willing to work, but are currently not looking for a job and therefore do not report unemployment status. According to our definition, all selected women are in the potential labor force. Those who have a paid job or are not employed, but are willing to work (involuntarily unemployed or a member of the hidden labor force reserve), are in the active labor force. To draw this distinction, we drew on the responses to a question posed to non-employed respondents: "Do you intend to engage in paid employment (again) in the future?" The women who stated "No, definitely not" were coded as 'not willing to work' and therefore not in the active labor force.

For the second part of the analysis we had to define employment. We decided to categorize women in regular full-time or part-time employment as employed. Consequently, women who stated that they were employed only marginally or irregularly were coded as nonemployed. The above definitions of the active labor force and employment result in a total of 4761 female respondents in the active labor force (either willing to work or already employed), 3320 of whom were employed.

Besides the individual level data from the GSOEP respondents, information on regional labor market characteristics was also needed. Determining the 'right' spatial level on which to measure access to opportunities is difficult (see HANSON et al., 1997 for an excellent discussion of this topic). For the purpose of this paper, the 2001 regional data for the 75 West German spatial planning regions (Raumordnungsregionen) were obtained from the German Federal Office for Building and Regional Planning (BUNDESAMT FÜR BAUWESEN UND RAUMORDNUNG, 2002). Using the Raumordnungsregion number for the GSOEP respondents' place of residence as a key variable, we were able to link regional data with individual data. We gratefully acknowledge the invaluable help of the data protection officer responsible for the GSOEP data, who granted us special permission to link these two sets of data. Three regional level variables were used in the analyses: the female unemployment rate, the mean traveling time to the agglomeration, and the number of childcare slots per 100 children.

On average, the Raumordnungsregionen have a size of 55 by 55 kilometers. These regions are large compared with those featured in the literature described above, in which the focus is on the micro geography of women's access to employment (see for example: HANSON and PRATT 1988, 1990; HANSON et al., 1997; KWAN 1999). By using these larger regions, the regional variable on, for example, childcare provision does not measure whether women have childcare available around the corner, but rather the average opportunity structure of childcare in the regional labor markets. In this way we could test whether the hypotheses derived from the literature used held on the scale of the regional labor markets for the whole of the western part of Germany.

Table 1 presents the variable summary statistics and definitions of the variables for the whole sample (willingness to work equation) and the sample of those willing to work 
(employment equation). In addition to the main variables mentioned in the theory section (age, level of education, household structure, additional income), some other control variables known to influence labor-force participation are also included in the model.

---- please insert Table 1 about here ----

\section{Methodology}

Theoretical considerations have two important implications for the methodology used. First, the cases in our model need to be clustered by region of residence (the 75 West German Raumordnungsregionen). The data include both individual level and regional characteristics; there is more than one respondent per region in our sample. Ignoring the nested nature of the data would violate the standard assumption of the independence of observations that underlies traditional regression models. Clustering the data by region in the model used resolves this problem (STATACORP, 2001).

Second, the two mechanisms of willingness to work and actually having a job have to be analysed in one model, because the two mechanisms cannot be seen separately. The relationship between the regional characteristics of the labor market and the women's probability of actually having a job is not straightforward. Those willing to work and therefore in the active labor force are a selective group, and it can be assumed that the selection process is related to our dependent variable (being in employment). If the regional labor market situation is poor, unwillingness to work may be a deliberately chosen strategy to avoid becoming non-employed. Because those most likely to be unemployed are those least likely to enter employment (VAN HAM et al., 2001), analysing employment while restricting the sample to those in the active labor force could lead to biased results. In the present study, we have accounted for sample selection bias by employing a variant of HECKMAN's (1979) two-step selection model. In the first step, the probability of willingness to work (be in the active labor force) is analysed. In the second step, the probability of actually being employed is analysed for those willing to work. Because the dependent variables in both the selection and the employment model are binary, a bivariate probit model with sample selection was used, following VAN DE VEN and VAN PRAAG (1981). ${ }^{1}$ Such a maximum-likelihood probit model with sample selection provides consistent, asymptotically efficient estimates for all parameters in the model (STATACORP, 2001).

When specifying a two-step model, one has to ensure that the model is properly identified (MANSKI, 1995). Strictly speaking, our model is basically identified by functional form because the bivariate probit model is nonlinear. However, we decided to adopt an additional strategy in order to avoid multicollinearity problems and to ensure the identification of the model. The key element of this strategy is to select at least one instrument variable that affects the decision to be in the active labor force, but not the probability of being employed. The difficulty here is that very similar factors can be expected to influence both the probability of willingness to have a paid job and the probability of actually having one since both selection processes can be expected to be very similar. Since a formal econometric test that could indicate the correct specification of the model was not available, any argument as to why specific variables are expected to influence one equation and not the other has to be of a substantive, theoretical nature. In our situation, we chose to use identical sets of regressors in both equations (because of the arguments given above), with the exception of the religion variable, which was only used in the in active labor force equation. Religion is needed to identify the model properly, although we acknowledge that including the variable adds little to the discussion. We have considered it likely that religion, as a proxy for traditional values, influences women's decisions on whether to be part of the active labor force, but not their employment risk, for two reasons. First, there are good theoretical arguments to suggest that religion does not significantly influence the probability that those in 
the active labor force will actually have a job. Second, we ran a model including the religion variable as a regressor in a single probit employment equation. This test produced very similar results to the employment equation with sample selection shown in the lower part of Table 2 , and yielded no significant effect of religion (not shown).

\section{RESULTS}

Table 2 presents the results of the full bivariate probit model with sample selection. First of all, the coefficient $\rho(0.404)$ that is significantly different from zero reveals that there is a positive correlation between the error terms of the willingness to work and employment equations. This correlation indicates that unmeasured respondent characteristics influence both the probability of willingness to work and the probability of being employed, and that correction for (self-)selection is therefore necessary. To give a substantive interpretation, the results indicate that women with unmeasured characteristics such as high motivation to be economically active are more likely to state that they want to work, and also more likely to be in paid employment.

---- please insert Table 2 about here ----

\section{Selection equation}

The results of the selection equation are presented in the top half of Table 2 . The dependent variable indicates whether respondents are willing to have a paid job (1) or not (0). The results found for the control variables are largely in line with the existing literature and are, therefore, only briefly discussed.

The probability of willingness to work is non-linearly related to age: with increasing age, the probability that women are willing to have a paid job first increases and then falls. This curve reflects the fact that the labor market participation of females is highest in the middle age group. As expected, the probability of willingness to work increases with the number of years in education. The more people have invested in their formal human capital, the more likely they are to want to realize a return on this investment in the form of a wage or salary (see BECKER, 1962, on the human capital theory).

Single women are more likely to be willing to have a paid job than women with a partner. This difference often reflects the outcome of a work specialization decision within households consisting of a couple. Note that this result is not influenced by monetary aspects, since we control for the financial contribution of the partner (if present) separately. Mothers with children under the age of 7 years are not significantly underrepresented among those willing to have a paid job. This noteworthy result reflects the high work orientation of young West German women, most of whom are educationally well prepared for an occupational career. The interaction effect between being single and having children under the age of 7 is not significant, indicating that single mothers are not less willing to work than other women.

With the increasing age of the youngest child, women become less likely to state that they want a paid job. This finding is contrary to what we expected and may reflect a growing disillusionment with earlier plans for combining family and work after childbirth, which is consistent with the discouraged worker hypothesis. The higher the additional household income (the net monthly household income minus the net monthly earnings of the respondent $)^{2}$, the lower is the probability that women state that they are willing to work. This reflects the well-known decreasing value of additional working hours supplied to the labor market by any household members. Female foreigners are less likely to express a willingness to work. On the one hand, this reluctance may reflect culturally differential labor market behavior; similarly, we observe that women defined as religious are underrepresented in the 
active labor force. On the other hand, the reduced labor market participation of female foreigners could also indicate discouragement effects induced by reduced labor market opportunities for this group. Such discouragement may also explain our finding that disabled women are underrepresented among those women who state that they want a paid job.

Of the three regional variables included in the equation, only the regional female unemployment rate has a significant impact on labor-force participation. The probability of being in the active labor force decreases as the regional rate of female unemployment increases. The fact that women in regions with a poor labor market more often state that they do not want to work indicates that these women are discouraged: they say they do not want to work because they perceive the probability of getting a paid job to be too low.

\section{Employment equation}

The results of the employment equation are given in the bottom half of Table 2 . The dependent variable indicates whether the respondents were employed (1) or not (0). The sample is restricted to those women in employment or not employed, but who stated that they were willing to work.

The effect of age on the probability of being employed is not significant. This result means that the chances of realizing an explicit will to work are equally distributed over the age groups. Again, this result is in line with the discouraged worker hypothesis, which suggests that groups with poor employment prospects, such as older people, tend to abandon their employment ambitions. As expected, the probability of being employed increases with years of education, an indication that employment prospects for the better educated are brighter.

Single women are more likely to be employed than women with a partner. This difference is consistent with the expectation that a dual job search is more difficult than a single job search and within the male breadwinner model the male job search has priority. The presence of children under 7 years in the household strongly decreases the probability of a woman's employment. This effect is by far the most pronounced in our model. Thus, although mothers with young children often express a wish to work (selection equation), they are far less able to realize their plans than women without young children. This indicates that there are high (institutional) barriers to employment for mothers with young children. We expected single mothers to be less likely to be employed than other women. Although the sign of the interaction effect is in the expected direction, the effect is not significant. This could be caused by the low number of single mothers in the dataset. We did find that the probability of being employed increases with the age of the youngest child - a well-known pattern (see also the section on women in the German labor market). Therefore, the results for these two variables in our two equations suggest that mothers with very young children would like to work, but cannot, because it is difficult to combine caring for a young child with a paid job. As the child grows older, discouraging effects increase, but for those who persist with their career plans it becomes easier to combine family and work.

In line with our expectations, the probability of being in employment decreases with increasing additional household income. The lower the economic pressure, the less necessary it is for those women who are in principle willing to work to accept jobs under unfavorable conditions. Disabled women and female foreigners are underrepresented in paid employment, even when controlling for their willingness to work. This under-representation may reflect some discrimination.

Again, three characteristics of the regional labor market were included in the analysis. All three are significant and have the expected effect on employment. With increasing regional female unemployment, the probability of being in paid employment decreases. It is a simple mechanism: the tighter the labor market, the more difficult it is to find a job. With increasing traveling time to the nearest agglomeration, the probability of being employed 
decreases. This result indicates that women facing poor local labor market conditions may escape them if a larger regional labor market is accessible within a reasonable commuting time. The third characteristic of the regional labor market included in the model is the number of childcare slots per 100 children in the regional labor market. This variable can be interpreted as an interaction effect with the variable indicating whether a child under age 7 lives in the household. The results show that the probability of being in paid employment increases as the number of childcare slots increases. This finding is also in line with our expectations. The better the access to childcare facilities, the easier it is for mothers to find a suitable job that allows family and work to be combined satisfactorily. This finding is of great policy relevance.

To sum up: our results show that the regional structure of employment opportunities affects female labor force participation in several ways. First of all, the regional female unemployment rate influences women's decisions on whether they actually want to work and become active on the labor market and, for those willing to work, the probability of actually having a job. This finding indicates a discouraged worker effect with respect to the decision to participate on the labor market. Second, as a proxy for access to employment opportunities, traveling time to the nearest concentration of jobs negatively influences the probability of being employed. Third, for mothers with young children, the availability of childcare facilities influences the probability of being in employment. Although mothers with young children do not state that they do not want to work more often than other women, they are less successful in finding suitable paid employment. Our findings indicate that an important explanation for this is a lack of sufficient childcare in the region of residence, which prevents these mothers combining the care of a young child with a paid job.

\section{SUMMARY AND CONCLUSION}

Most micro-economic approaches to understanding female labor-force participation place a heavy emphasis on personal and household characteristics. Following a long tradition in geography of considering the constraints of local labor market conditions in understanding labor-force participation, this paper explicitly included the effect of regional structures on female employment. The main argument of this paper was that the effect of these regional structures on female employment was too complicated simply to study employment versus non-employment. It was argued that, in order to understand the mechanisms at play, two phases of participation should be distinguished: the willingness to have a paid job and, for those willing to work, actually having a job. This approach makes it possible to discern the extent to which poor labor market conditions discourage women in the potential labor force and thus affect female labor force participation. We hypothesised that poor access to employment opportunities would negatively influence the probability of willingness to work and the probability that those willing to work are actually in paid employment.

We utilized two special features of our data in testing our hypotheses. First, the German Socio-Economic Panel includes some unique variables on whether or not nonemployed respondents are willing to look for a paid job in the future. We were thus able to distinguish three groups of women: non-employed women not willing to have a paid job; nonemployed women willing to have a paid job; and employed women. To analyse this data structure, we used a variant of the Heckman two-step procedure, which allowed selective access to the active labor force to be controlled. A second special feature of our dataset was that it allowed the characteristics of the regional labor market to be linked to the individual respondents based in that region as residents. The lack of such a possibility in many datasets might be the reason for many studies placing such a heavy emphasis on personal 
characteristics and not on conditions that are external to the individual (ODLAND and ELLIS, 1998).

Testing our framework for the West German labor market confirmed the hypothesis that poor labor market conditions may discourage some women from participating on the labor market. The results show that women living in a region with a high regional female unemployment rate are less likely to state that they would like a paid job. Contrary to what we expected, we did not find any discouraging effects associated with a long traveling time to agglomerations or poor access to childcare facilities for mothers. For those women who were willing to work, on the other hand, all controlled characteristics of the regional labor market had the expected effect on the probability of being employed. The higher the regional female unemployment rate, the longer the traveling time to the nearest concentration of employment opportunities, and - for mothers - the poorer the regional provision of childcare, the lower the probability of finding a suitable job. The two-step approach used in this paper demonstrates that the structure of the regional labor market plays a part in both phases of female labor force participation, but that spatial barriers to employment have their main role in the second phase: those willing to engage in paid employment actually finding a job.

In this paper, we included labor market characteristics on the regional level. Many of the studies mentioned in the literature review section of this paper concentrate on the micro geography of female labor force participation (see, for example, the work by Hanson and Pratt). These studies have provided important insights into the mechanisms at play on a fine spatial scale. In this study, we tested whether labor market characteristics influence female labor market participation at the level of regional labor markets for the whole of the western part of Germany. With regard to access to childcare, for example, we measured the overall shortage of childcare facilities on regional labor markets. The fact that childcare provision has an effect on this regional scale is a strong indication of the importance of good geographical access to childcare facilities as a precondition for access to job opportunities.

One of the most interesting findings of our study was that women with children are no less willing to work than women without children and that there was no effect of the availability of childcare on a mother's willingness to work. These results reflect the high work orientation of young West German women. The analysis also showed that, as the age of the youngest child increases, women become less likely to state that they would like a paid job. This finding may reflect that, as their children get older, non-employed mothers become discouraged. The distinction revealed in the two phases of participation showed that, although mothers are no less willing to work than women without children, those with a child under 7 years encounter most difficulties in finding a job. The results indicate that a shortage of childcare on the regional level plays an important part in explaining the negative effect of having young children on having a paid job. This finding is of high policy relevance because it shows that mothers face serious barriers to employment. Besides the effect of a shortage of childcare on the regional level, the relatively generous German social security system may also be counterproductive in failing to encourage non-employed mothers willing to work to actually seek paid labor. In this light, it would be interesting to compare Germany with other countries with different social security systems.

The main conclusion of this study is that poor regional labor market characteristics not only influence the probability of being in employment for those willing to work, but also affect, at an earlier stage of the decision-making process, the willingness to work. Furthermore, drawing the formal distinction between willingness to work and the ability to do so gives much more insight into the obstruction mechanisms blocking the road to female employment than would be possible with a traditional research design that only analysed female employment versus unemployment. Drawing this distinction made it possible to discern a differential effect of the presence and age structure of young children in the household on mothers' willingness and ability to work. Applying this advanced methodology 
may help policymakers support female employment in more specific terms and at an earlier point of intervention. Further research may seek to assist these actors by working with more highly differentiated and more detailed spatial indicators than was possible at this stage.

Acknowledgements - My co-author, Prof. Dr Felix Büchel died at the age of 47 on the $12^{\text {th }}$ of July 2004. This paper was one of the last products we worked on together. I am very grateful to have had the opportunity to work with him over the last few years. I am also grateful to the Max Planck Institute for Human Development in Berlin for their kind invitation and financial support for a two-month research period as a guest scientist in 2003 and to the Amsterdam institute for Metropolitan and International Development Studies (AMIDSt) at the University of Amsterdam for the opportunity to spend some of my contract time abroad. Finally, I would like to thank Pieter Hooimeijer, the editors of Regional Studies, and the anonymous referees for their literature suggestions and useful comments on earlier versions of this paper.

\section{NOTES}

1. The two-step selection model is often estimated by obtaining the inverse Mill's Ratio from a first stage probit, and entering it into the second stage equation. As noted by VAN DE VEN and VAN PRAAG (1981), if the dependent variable in the second stage equation is binary, the error term is not normally distributed; a two-stage approach to this problem would therefore yield only approximate results.

2. We correct for household size and composition using the so-called modified OECD equivalent scale (weights are: head of household $=1$; other household members aged 16 years and older $=0.7$; children up to 16 years $=0.5$ ).

\section{REFERENCES}

BECKER G. (1962) Human capital: a theoretical and empirical analysis, Journal of Political Economy 70, 9-46.

BECKER G. (1976) The economic approach to human behavior. University of Chicago Press, Chicago.

BECKER, G. (1991) A treatise on the family (Enlarged Edition ed.). Harvard University Press, Cambridge, MA.

BERGER M. C. and BLACK D. A. (1992) Child care subsidies, quality of care, and the labor supply of low-income, single mothers. Review of Economics and Statistics 74, 635-642.

BLAU D. M. and HAGY A. P. (1998) The demand for quality in child care. Journal of Political Economy 106, 104-146.

BLAU D. and ROBINS P. (1988) Child-care costs and female labor supply, Review of Economics and Statistics 70, 374-381.

BLAU D. and ROBINS P. (1991) Child care demand and labor supply of young mothers over time, Demography 28, 333-351.

BÜCHEL F. and SPIESS C.K. (2002) Form der Kinderbetreuung und Arbeidsmarktverhalten von Müttern in West- und Ostdeutschland [Childcare arangements and labor market behaviour of women in West and East Germany]. Band 220 Schriftreihe des Bundesministeriums für Familie, Senioren, Frauen und Jugend. Kohlhammer. Stuttgart.

BÜCHEL F. and VAN HAM M. (2003) Overeducation, regional labor markets and spatial flexibility, Journal of Urban Economy 53, 482-493. 
BUNDESAMT FÜR BAUWESEN UND RAUMORDNUNG (BBR; German Federal Office for Building and Regional Planning) (2002) Aktuelle Daten zur Entwicklung der Städte, Kreise und Gemeinden. Ausgabe 2002 [Current Data on the Development of Cities, Districts and Municipalities. 2002 Edition]. BBR. Bonn.

CONNELY R. (1991) The importance of child care costs to women's decision making, in BLAU D. M. (Ed) The economics of child care, 87-118. Sage Foundation, New York.

CONNELY R. (1992) The effect of child care costs on married women's labor force participation. The Review of Economics and Statistics 74, 83-90.

DIW (2003) Hohe Lebenszufriedenheit teilzeitbeschäftigter Mütter [High satisfaction with life for part-time working mothers]. Wochenbericht des DIW Berlin 35/03. DIW, Berlin.

ENGLAND K. (1996a) Mothers, wives, workers: The everyday lives of working mother, in ENGLAND K. (Ed) Who Will Mind the Baby? pp. 109-122. Routledge. London.

ENGLAND K. (1996b) Who will mind the baby?, in ENGLAND K. (Ed) Who Will Mind the Baby? pp. 3-19. Routledge. London.

ENGSTLER H. (1998) Die Familie im Spiegel der amtlichen Statistiek [Families in government statistics]. Brühl. Chudeck.

ERMISCH J. (1989) Purchased child care, optimal family size and mothers'employment: theory and econometric analysis, Population Economics 2, 79-102.

FISHER M. M. and NIJKAMP P. (1987) Spatial labor market analysis: relevance and scope, in FISHER M. M. and NIJKAMP P. (Eds) Regional Labor Markets. pp. 1-36. North Holland. Amsterdam.

GILBERT M. R. (1998) "Race," space, and power: the survival strategies of working poor women, Annals of the American Association of Geographers 88, 595-621.

GORDON P., KUMAR A. and RICHARDSON H. W. (1989) Gender differences in metropolitan travel behaviour, Regional Studies 23, 499-510.

HANSON S., KOMINIAK T. and CARLIN S. (1997) Assessing the impact of location on women's labor market outcomes: a methodological exploration, Geographical Analysis 29, 281-297.

HANSON S. and PRATT G. (1988) Spatial dimensions of the gender division of labor in a local labor market, Urban Geography 9, 180-202.

HANSON S. and PRATT G. (1990) Geographic perspectives on the occupational segregation of women, National Geographic Research 6, 376-399.

HANSON S. and PRATT G. (1991) Job search and the occupational segregation of women, Annals of the American Association of Geographers 81, 229-253.

HANSON S. and PRATT G. (1995) Gender, Work and Space. Routledge. London.

HECKMAN J. (1974) Effects of child-care programs on women's work effort. Journal of Political Economy 82, 136-169.

HECKMAN J. (1979) Sample selection bias as a specification error. Econometrica 47, 153161.

HENKENS K., MEIJER L. and SIEGERS J. (1993) The labour supply of married and cohabiting women in the Netherlands, 1981-1989, European Journal of Population 9, 331-352.

HOLST E. and SCHUPP J. (2001) Erwerbsverhalten von Frauen [Female labor market behaviour]. Wochenbericht des DIW (42/01). Berlin.

JOHNSTON-ANUMONWO I. (1992) The influence of household type on gender differences in work trip distance, The Professional Geographer 44, 161-169.

KAIN J. (1968) Housing segregation, negro employment, and metropolitan decentralization, Quarterly Journal of Economics 82, 175-197.

KLAMMER U., KLENNER C., OCHS C., RADKE P. and ZIEGLER A. (2000) WSI Frauen Daten Report [WSI-data report on women]. Hans-Böckler-Stiftung Düsseldorf. Berlin. 
KWAN M.-P. (1999) Gender and individual access to urban opportunities: a study using space-time measures, The Professional Geographer 51, 210-227.

LEIBOWITZ A., KLERMAN J. and WAITE L. (1992) Employment of new mothers and child care choice, Journal of Human Resources 27, 112-134.

MADDEN J. F. (1981) Why women work closer to home, Urban Studies 18, 181-194.

MANSKI C.F. (1995) Identification problems in the Social Sciences. Harvard University Press. Cambridge, MA.

MCGINNITY F. (2002) The labour-force participation of the wives of unemployed men: comparing britain and west germany using longitudinal data. European Sociological Review 18, 473-488.

MENCKEN F. C. and WINFIELD I. (2000) Job search and sex segregation: Does sex of social contact matter? Sex Roles 42, 847-864.

MICHELSON W. (1985) From Sun to Sun: Daily Obligations and Community Structure in the Lives of Employed Women and Their Families. Rowman and Allanheld. Totowa, NJ.

MICHELSON W. (1988) Divergent convergence: The daily routines of employed spouses as a public affairs agenda, in ANDREW C. and MILROY B. M. (Eds) Life Spaces: Gender, Household, Employment. pp. 81-101. University of British Columbia Press. Vancouver.

MOSELEY M.J. and DARBY J. (1978) The determinants of female activity rates in rural areas: an analysis of Norfolk parishes, Regional Studies 12, 297-309.

ODLAND J. and ELLIS M. (1998) Variations in the labour force experience of women across large metropolitan areas in the united states. Regional Studies 32, 333-347.

PRATT G. and HANSON S. (1991) Time, space, and the occupational segregation of women: a critique of human capital theory, Geoforum 22, 149-157.

PRESTON V. and MCLAFFERTY S. (1999) Spatial mismatch research in the 1990s: progress and potential, Papers in Regional Science 78, 387-402.

RESKIN B. (1993) Sex segregation in the workplace. Annual Review Of Sociology 19, 241270.

ROUWENDAL J. (1999) Spatial job search and commuting distances. Regional Science and Urban Economics 29, 491-517.

RUBERY J., SMITH M., FAGAN C. and GRIMSHAW D. (1998) Women and European employment. Routledge, London and New York.

RUBERY J., SMITH M. and FAGAN C. (1999) Women's employment in europe. Trends and prospects. Routledge, London and New York.

SIMPSON W. (1992) Urban structure and the labor market: worker mobility, commuting and underemployment in cities. Clarendon Press. Oxford.

SOEP GROUP (2001) The German Socio-Economic Panel (GSOEP) after more than 15 years - Overview, in HOLST E., LILLARD D.R. and DIPRETE T. A. (Eds) Proceedings of the 2000 Fourth International Conference of German Socio-Economic Panel Study Users, Vierteljahrshefte zur Wirtschaftsforschung 70, 7-14.

STATACORP (2001) Stata Statistical Software: Release 7.0. Stata Corporation. College Station, TX.

STATISTISCHES BUNDESAMT (2001) Statistisches Jahrbuch für die Bundesrepubliek Deutschland [Statistical yearbook for Germany]. Metzler-Poeschel. Stuttgart.

STATISTISCHES BUNDESAMT (2002) Leben und Arbeiten in Deutschland. Ergebnisse des Mikrozensus 2001 [Living and working in Germany. Results of the 2001 microcensus]. Statistisches Bundesamt. Wiesbaden.

STATISTISCHES BUNDESAMT (2003) Löhne und Gehälter in Deutschland [Wages in Germany]. Statistische Bundesamt, Wiesbaden. 
STATISTISCHES BUNDESAMT (2004) Mikrozensus 2003: Erwerbstätigkeit von Muttern steigt [Increasing labor participation of mothers]. Press release, 28th of April 2004. Statistisches Bundesamt. Wiesbaden.

TIVERS J. (1985) Women Attached: The Daily Lives of Women with Young Children. Croom Helm. London.

TIVERS J. (1988) Women with young children: Constraints on activities in the urban environment, in LITTLE J., PEAKE L. and RICHARDSON P. (Eds) Women in Cities: Gender and the Urban Environment. pp. 84-97. New York University Press. New York.

VAN DER LIPPE T. and VAN DIJK L. (2002) Comparative research on women's employment, Annual Review of Sociology 28, 221-241.

VAN DE VEN W. P. M. M. and VAN PRAAG B. M. S. (1981) The demand for deductibles in private health insurance: a probit model with sample selection, Journal of Econometrics 17, 229-252.

VAN DIJK L. and SIEGERS J. (1996) The effect of the supply of subsidized day-care facilities on female labor supply, Labor: Review of Labor Economics and Industrial Relations 10, 559-582.

VAN HAM M. (2002) Job access, workplace mobility, and occupational achievement. Eburon. Delft.

VAN HAM M., MULDER C. H. and HOOIMEIJER P. (2001) Local underemployment and the discouraged worker effect, Urban Studies 38, 1733-1751.

VAN HAM M. and MULDER C.H. (2003) Geographical access to childcare and mothers' labor-force participation, Tijdschrift voor Economische en Sociale Geografie 96, 63-74.

WAGNER G., BURKHAUSER, R. V. and BEHRINGER, F. (1993) The English Language Public Use File of the German Socio-Economic Panel Study, Journal of Human Resources 28, 429-433.

WARD C. and DALE A. (1992) Geographical variation in female labour force participation: an application of multilevel modelling, Regional Studies 26, 243-255 
Table 1 Variable summary statistics and definitions

Willingness to work equation $(\mathrm{N}=\mathbf{5 5 0 8})$

$\begin{array}{rrc}\text { Mean } & \text { Std. Dev. } & \text { Range } \\ & & \\ 0.86 & & 0-1 \\ 40.97 & 10.41 & 18-60 \\ 11.63 & 2.46 & 7-18 \\ 0.17 & & 0-1 \\ 0.23 & & 0-1 \\ 3.03 & 0.85 & 0-6 \\ 1.56 & 1.15 & 0-11.94 \\ 0.07 & & 0-1 \\ 0.14 & & 0-1 \\ 0.21 & & 0-1 \\ 4.90 & 1.42 & 2.30-9.70 \\ 1.22 & 0.36 & 0.75-2.22 \\ 56.87 & 7.70 & 39.40-82.70\end{array}$

Dependent: willing to work $(1=$ willing $)$

Age (in years)

Education (in years)

Single $(1=$ no partner present $)$

Child(ren) up to 7 years $(1=$ child(ren) present $)$

Age of youngest child under 7 years

Additional household income (in $1000 \mathrm{DM})^{\mathrm{a}}$

Disabled $^{\mathrm{b}}(1=$ disabled $)$

Foreigner $^{\mathrm{c}}(1=$ foreigner $)$

Religious $^{\mathrm{d}}(1=$ religious $)$

Female unemployment rate in region ${ }^{\mathrm{e}}$

Traveling time to agglomeration ${ }^{\mathrm{f}}$

Childcare slots per 100 children in region $^{\mathrm{g}}$

$7.70 \quad 39.40-82.70$

\section{Employment equation $(\mathrm{N}=\mathbf{4 7 6 1})$}

Dependent: employment $(1=$ employed $)$

Age (in years)

0.70

$0-1$

Education (in years)

39.66

$9.90 \quad 18-60$

Single $(1=$ no partner present $)$

11.81

$2.47 \quad 7-18$

Child(ren) up to 7 years $(1=$ child(ren) present $)$

0.18

$0-1$

0.24

Age of youngest child under 7 years

3.02

Additional household income (in 1000 DM) ${ }^{\mathrm{a}}$

1.49

Disabled $^{\mathrm{b}}(1=$ disabled $)$

0.05

Foreigner $^{\mathrm{c}}(1=$ foreigner $)$

0.12

4.88

1.22

56.94

Female unemployment rate in region

Traveling time to agglomeration ${ }^{\mathrm{f}}$

Childcare slots per 100 children in region ${ }^{\mathrm{g}}$

$\begin{array}{cc} & 0-1 \\ & 0-1 \\ 0.88 & 0-6 \\ 1.12 & 0-11.94 \\ & 0-1 \\ & 0-1 \\ 1.44 & 2.30-9.70 \\ 0.35 & 0.75-2.22 \\ 7.76 & 39.40-82.70\end{array}$

${ }^{a}$ Additional household income is defined as the equivalized net monthly household income minus the net monthly earnings of the respondent

${ }^{b}$ Respondents are defined as disabled if they state that their health situation "strongly" impedes their performance of daily activities

${ }^{c}$ Respondents are defined as foreigners if they do not have German nationality

${ }^{\mathrm{d}}$ Respondents are defined as religious if they state that they attend church or other religious events every week

${ }^{\mathrm{e}}$ Unemployed women per 100 women (15-65 years old), regional level data

${ }^{\mathrm{f}}$ Average travel time in hours to the nearest three agglomerations by car, regional level data

${ }^{\mathrm{g}}$ Number of childcare slots per 100 children up to 6 years old, regional level data (measured on 01.01.1999)

Source: Own calculations based on GSOEP data, matched with regional data from the German Federal Office for Building and Regional Planning (both for 2001, West Germany only). 
